\title{
POTENTIAL MARINE-DERIVED FUNGI ISOLATED FROM SPONGE IN PRODUCE NEW AND BENEFICIAL COMPOUNDS
}

\author{
Wendy Alexander Tanod ${ }^{1 *}$, Muliadin ${ }^{1)}$, Yeldi S. Adel ${ }^{1)}$ and Didit Kustantio Dewanto ${ }^{1)}$ \\ ${ }^{1}$ Sekolah Tinggi Perikanan dan Kelautan (Institute of Fisheries and Marine), \\ Jl. Soekarno Hatta KM 6, Mantikulore, Palu, Central Sulawesi \\ * Corresponding author : wendytanod@stplpalu.ac.id
}

\begin{abstract}
Marine organisms are a source of natural products and produce compounds with a molecular structure that is unique and useful. Thousands of new compounds have biological activitity for anticancer, antiviral, and antimicrobial. This compounds isolated from various marine organism, including from marine-derived fungi. Investigation of chemical compounds from marine-derived fungi isolated from sponge has increased steadily, indicating the important role of marine-derived fungi in the discovery of drug compounds. The sponge has produced various kinds of fungi, which have reported to provide a variety of pharmacologically active metabolites and structurally diverse. Study literature showed that many fungal genera isolated from the marine sponge dominated the genus Acremonium, Aspergillus, Penicillium, Phoma, and Fusarium. The high proportion of genera and new compounds showed that the fungi isolated from the sponge could develop.
\end{abstract}

\section{Keywords : Fungi, Marine, Natural Products, Secondary Metabolite}

\section{INTRODUCTION}

Marine organisms have been a rich source of natural products that have a high diversity in the molecular structure and bioactivity (Koenig et al., 2006; and Dewanto et al., 2018; 2019). Marine organisms produce many new compounds with some amazing pharmacological properties (Faulkner, 2000; Mayor and Lehman, 2001; Garcia et al., 2002; Proksch et al., 2002; Amador et al., 2003; Haefner, 2003; Mayer et al., 2003; and Alhaddad et al., 2019). Over the past twenty years, thousands of new compounds and their metabolites with biological activity varied from antiviral, anticancer, antimicrobial have isolated from various marine organism (Faulkner, 2000; Garcia et al., 2002; Amador et al., 2003; Haefner, 2003; and Tanod et al., 2018).

Drug substances from the marine currently hold more than 35000 samples, with about 150 compounds be cytotoxic to tumor cells (Garcia et al., 2002). Many natural products are efficacious, showed cytotoxic activity, and effective anticancer found in the marine environment
(Wijesekara et al., 2014). Since 1990, there has been increase in the number of preclinical anticancer compounds from marine organism that have entered into clinical trials in humans (Lordan et al., 2011).

Investigation of chemical compounds from fungi isolated from marine organism such as algae (Lee et al., 2013), sponge (Proksch et al., 2010) and tunicates (Schmidt et al., 2012) has increased steadily, indicating an important role of marine fungi in the discovery of drug compounds. Fungal organisms become an integral part of life in the biosphere because the fungus has many functional roles in different ecosystems. Obligate marinederived fungi are fungi that grow and sporulate exclusively in estuarine or marine habitats. Facultative marine-derived fungi are fungi from freshwater or terrestrial habitats are able to grow, and may also sporulate, in the marine environment (Velmurugan et al., 2013). Marine derived fungi are heterotrophic microorganisms that can be found in a variety of substrates as saprophytic and parasitic (Raghukumar, 1990). All groups of fungi including higher 
filamentous fungi, yeasts, and fungi thrust chytrids and zoospores, in the form of a saprophyte on detritus as well as parasites on plants and animals in the marine environment. However, a group of fungi varies greatly in different marine ecosystems. There are over 100,000 species of fungi (Blackwell, 2011).

In recent years, there has been evidence that the production of secondary metabolites by the organism is not random, but correlated with ecological niches (Gloer, 1995, 1997). Thus, the chemists trying to isolate microorganisms from unexplored ecological habitats. While macroorganism sea has long been a target for chemical investigation, investigation of marine microorganisms dominated by fungi and bacteria wider attention (Faulkner, 1998). Vasanthabharathi and Jayalakshmi (2013) marine microorganisms have the potential genetic and biochemical diversity of large and become a source of new and effective drugs. Secondary metabolites produced by marine microorganisms are also believed to act as a chemical defense system in the competition for the host (Gallo et al; 2004).

Marine-derived fungus is a rich source of structurally diverse bioactive secondary metabolites with a structure that has never been encountered before and have shown biological activity of a variety of health benefits (Blunt et al., 2006; Smetania et al., 2007). A number of metabolites from marine-derived fungi have antioxidant activity, antimicrobial, anti-tyrosinase or skin lightening, cytotoxic or antitumor, induction of quinone reductase, and anti plasmodial activity. Until recently, many of the structures and pharmacology of bioactive secondary metabolites new and exciting has been isolated from marinederived fungi. Secondary metabolites produced by marine organisms including marine-derived fungi have a structure that is unique and new (Wijesekara et al., 2014). Marine derived fungi also been reported produce antibacterial compounds (Bugni and Ireland, 2004; Saleem et al., 2007; and Rateb and Ebel, 2011). Marine-derived fungi have been isolated from almost every marine habitat as possible, including inorganic materials, microbial communities, plants, invertebrates and vertebrates. In particular, the sponge has produced various kinds of fungi, which have been reported to produce a variety of pharmacologically active metabolites and structurally diverse. Marine derived fungi require adaptation and survival in an environment that differs significantly from terrestrial organisms. This may have formed a pattern of their natural products that marine-derived fungi can result in the production of secondary metabolites unique. In this article will discuss the potential of marine-derived fungi were isolated from the sponge as a basic discovery of new compounds is efficacious.

\section{Marine Derived Fungi Secondary Metabolites Isolated From Sponges}

Sponge has been recognized not only as a productive source of bioactive secondary metabolites, but also as a harbor microorganisms such as fungi (Gao et al., 2008). A recent review has shown that of the sponge-derived fungi is the main source for new secondary metabolites (Rateb and Ebel, 2002).

Marine-derived fungi Gymnascella dankaliensis isolated from a sponge reported produces two classes of cytotoxic secondary metabolites, polyketides tyrosine and steroid derivatives (Amagata et al., 2013). This fungi isolated from gymnastatin A (1), dankastatin A (2), dankastatin C (3) and demethylincisterol $\mathrm{A}_{3}(4)$ as can be seen in Figure 1. The compound demethylincisterol $\mathrm{A}_{3}$ is also produced by the sponge Homaxinella (Mansoor et al., 2005 ) from the research dankastatin $\mathrm{C}$ is a potential cytotoxic. 


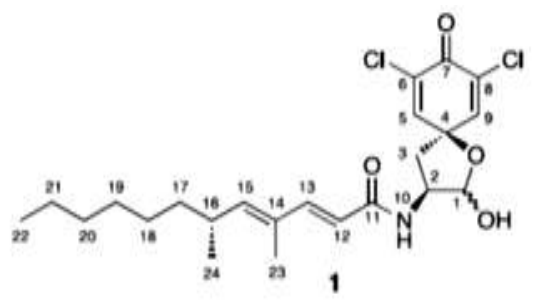<smiles>CCCCCCC(C)/C=C(C)/C=C/C(=O)NC1CC2(O)C(Cl)C(=O)C(Cl)=CC2(O)OC1OC</smiles><smiles>CCCCCCC(C)/C=C/C(C)=C/C(=O)NCC1(O)C(OC)C(O)C2(O)C(Cl)=C(Cl)C(=O)C12O</smiles>

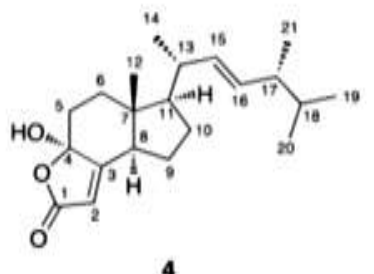

Figure 1. Secondary Metabolites of Gymnascella dankaliensis

Metabolite of marine-derived fungi Penicillium chrysogenum isolated from the Mediterranean sponge Ircinia fasciculata known to produce sorbicillactone A (5),

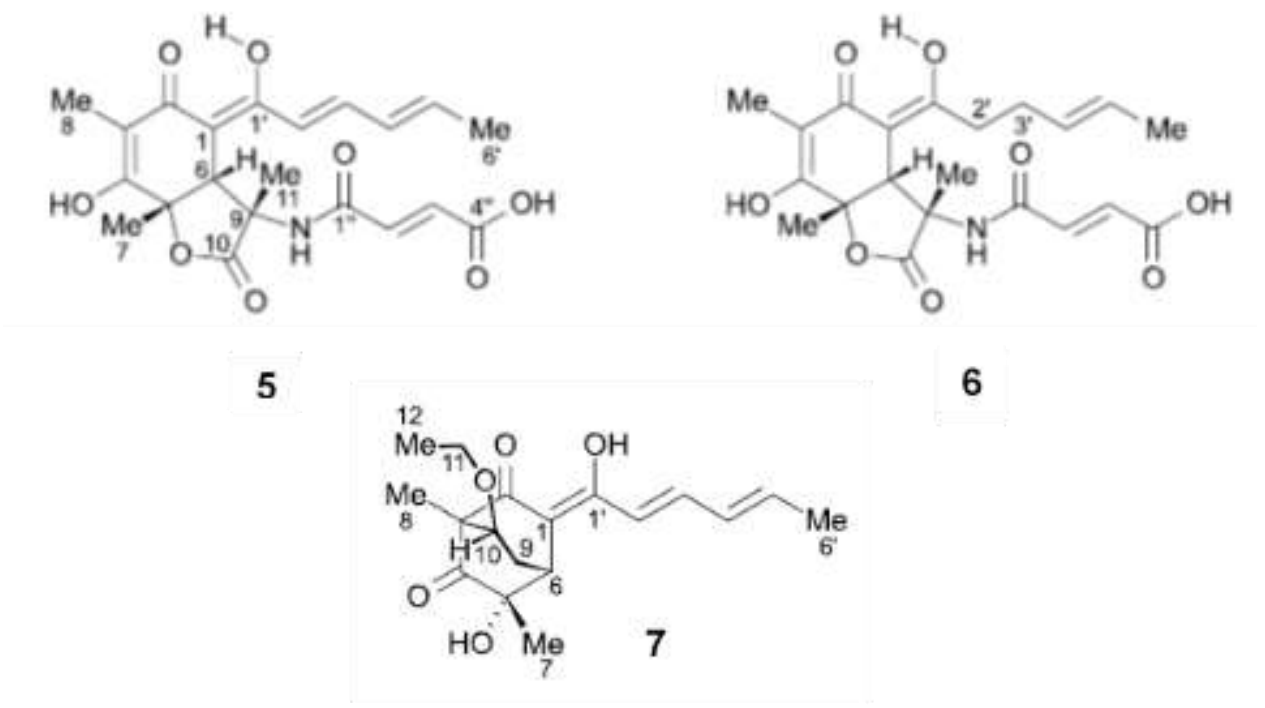

sorbicillactone B (6) and sorbivinetone (7) (Figure 2) that show anti-leukemia activity (Bringmann et al., 2005).

Figure 2. Secondary Metabolites of Penicillium chrysogenum

Sesquiterpenoid bisabolane phenolic compounds, disydonols A-C (8-10) (Figure $3)$, together with (S)-(+)-sydonol (11) compound (Nukina et al., 1981 and Kudo et al., 2009) isolated from marine derived fungi Aspergillus sp. of sponge Xestospongia testudinaria (Sun et al., 2012). Compounds 8 and 10 showed cytotoxic potential against tumor cell lines.
Sesquiterpenoid bisabolane phenolic compound first isolated from the gorgonian coral Pseudopterogorgia rigida (McEnroe and Fenical, 1978). Compounds of this type are also reported to be isolated from the sponge Didiscus flavus (Wright et al., 1987), Didiscus sp. (Tasdemir et al., 2003), Epipolasis sp. (Fusetani et al., 1987) and Arenochalina sp. (Butler et al., 1991). 
Sesquiterpenoids bisabolane phenolic compounds group also found in marinederived fungi Penicillium expansum (Lu et al., 2010), Aspergillus sydowi (Hamasaki et

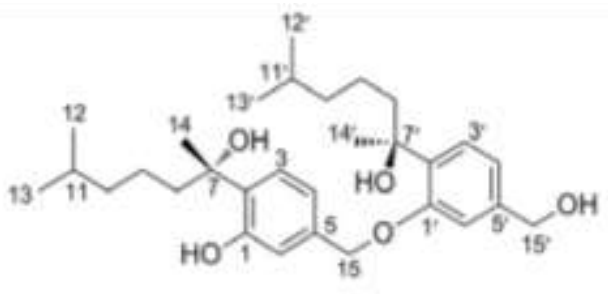

8

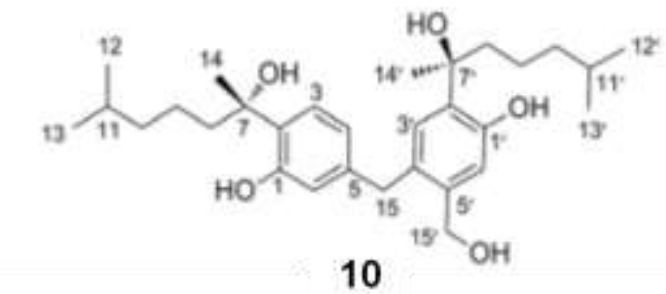

al., 1978), Aspergillus sp. (Nukina et al., 1981 and Wei et al., 2010), Penicillium sp. (Henne et al., 1993) and the fungus CNC979 (Mülhaupt, et al., 2005).
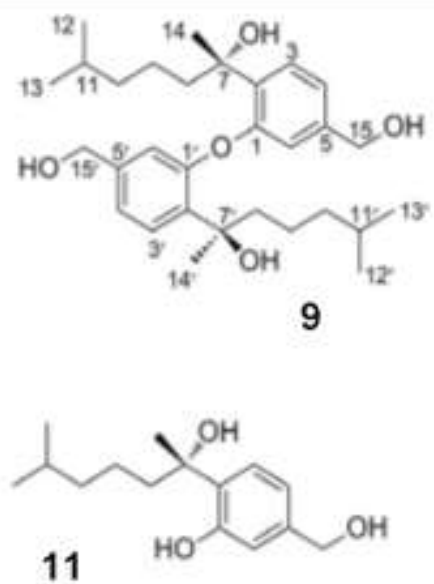

Figure 3. Secondary Metabolites of Aspergillus sp.

Four meroterpenoid cytotoxic has been isolated from plants, compounds, tropolactones A-D $(12,13,14,15)$ (Figure 4), which was isolated from the genus marine-derived fungi Aspergillus using extract broth (Cueto, MacMillan, Jensen, \& Fenical, 2006). This fungus was isolated from a sponge that has not been identified and collected from the Gulf Manele, Hawaii. Meroterpenoid is a compound mixture of terpenes and polyketide biosynthesis, which microorganisms and invertebrates. In 1970, meroterpenoid compound andibenin B (16) (Dunn et al., 1976) and andilesin A (17) (Dunn et al., 1978) have been isolated from the terrestrial fungi Aspergillus variecolor. Isolation tropolactones A-D compound based investigation continues from marine fungi as a source of bioactive metabolites (Bugni and Ireland, 2004; Tan et al., 2004; Rowley et al., 2003; Cueto et al., 2002).
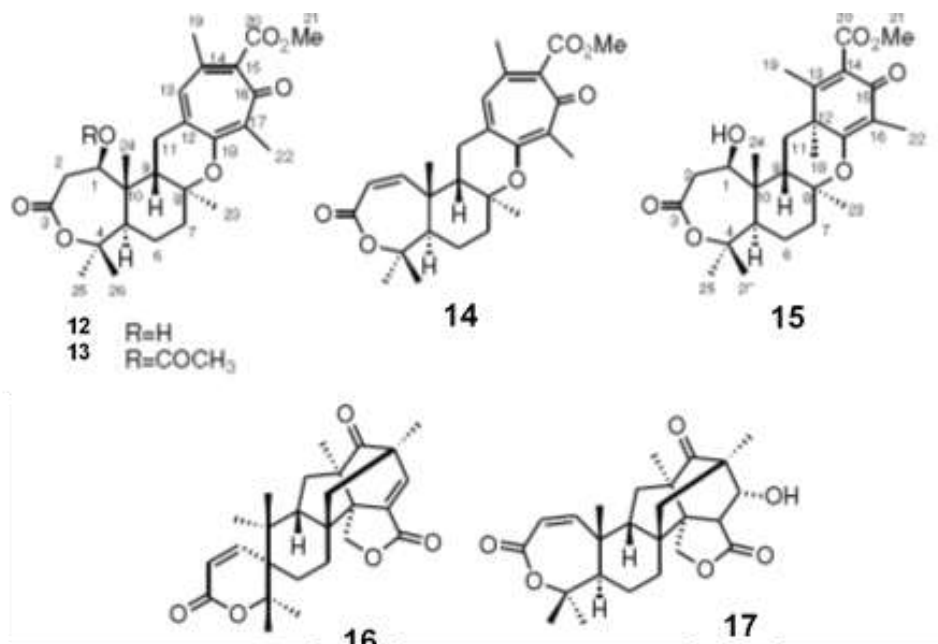

Figure 4. Secondary Metabolites of Aspergillus 
New diketopiperazine dimer, eurocristatine (18) (Figure 5) isolated from marine-derived fungi Eurotium cristatum KUFC 7356 of sponge (Gomes et al., 2012). Species Eurotium a sexual state of Aspergillus species, especially Aspergillus glaucus group (Geiser, 2009). Almeida et al., (2010) reported the ethyl acetate extract Eurotium cristatum KUFC 7356 isolated from the sponge showed growth inhibitory activity of three cancer cell lines. Even though some diketopiperazine dimers have been reported previously from a variety of fungal sources, and especially from Aspergillus species (Barrow et al., 1993; Barrow and Sedlock., 1994; Cai et al., 2012; Ding et al., 2008; Li et al. 2009; Ovenden et al., 2004; Ruju et al., 2009; Son et al., 1999; Takahashi et al., 1994, 1995a, b; Varoglu et al., 1997; Yamada et al., 2002), eurocristatine a diketopiperazine dimer which was first isolated from the genus Eurotium. Eurocristatine structure closely resembles diketopiperazine dimer isolated from marine-derived fungi Aspergillus niger (Ovenden et al., 2004). Although eurocristatine not shown cytotoxic activity, antibacterial or antifungal, but eurocristatine a new compound isolated from a group of fungi.

The new compound triprofan is a derivative alkaloid, 3 - ((1-hydroxy-3-(2methylbut-3-en-2-yl)-2-oxoindolin-3- yl)methyl)-1-methyl-3,4

dihydrobenzo[e][1,4] diazepine-2,5-dione

(19), and the new compound meroterpenoid, austalide R (20, 24, 25), as well as three compounds 8-O-4dehydrodiferulic acid (21) (Bunzel et al., 2003 and Funk et al., 2005), cytochalasin Z17 (22) (Lin et al., 2009), and dihydroisoflavipucin (23) (Loesgen et al., 2011) (Figure 6) are produced by marinederived fungi Aspergillus sp. isolated from the Mediterranean sponge Tethya aurantium (Zhou et al., 2014). Cytochalasin Z17 have previously been isolated from Aspergillus terreus and Aspergillus flavus obtained of Artemisia annua and mangrove Acanthus ilicifolius (Lin et al., 2009 and Zhang et al., 2010). Dihydroisoflavipucin has also been isolated from Phoma sp. of Salsola oppositifolia (Loesgen et al., 2011). However, both of these compounds were first reported isolation of fungi isolated from sponge (Zhou et al., 2014). All of these compounds proved to be active against strains of L5178Y murine cancer cells in a cytotoxicity assay. The resulting compound selectively inhibits marine bacterial strains. This is very interesting because it can improve the prospects of produce compounds such as antifouling agents or to fight against epizootics in aquaculture in the future (Zhou et al., 2014).

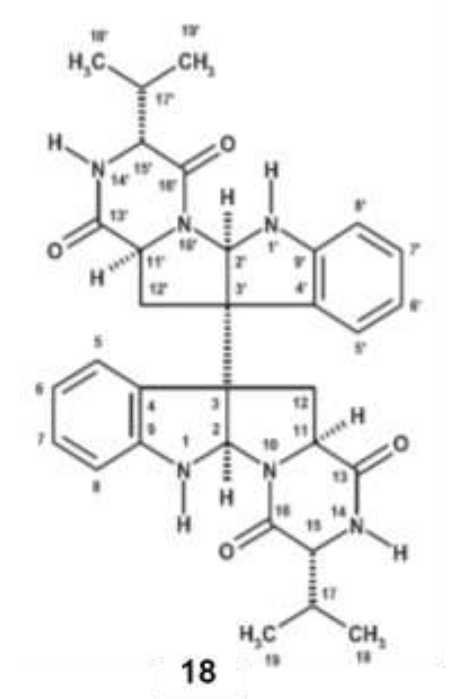

Figure 5. Secondary Metabolites of Eurotium cristatum KUFC 7356 


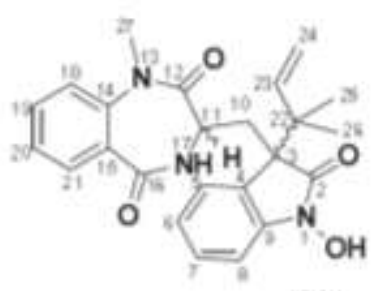

19

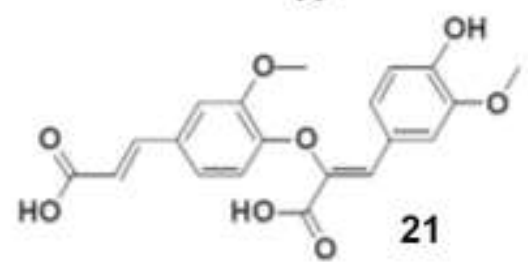

21

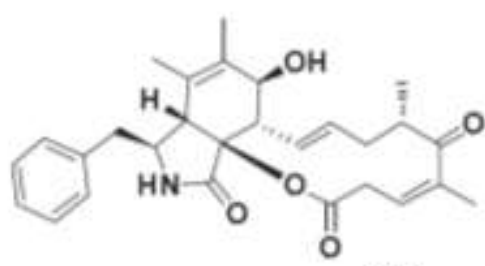

22

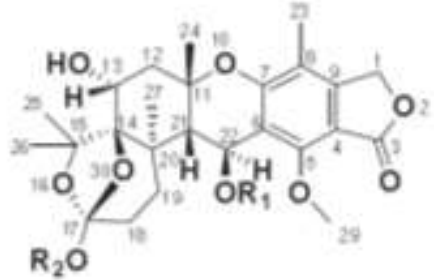

$20 \quad R_{1}=H_{1} R_{2}=H$

$24 \quad R_{1}=R_{2}=M e$

$25 R_{1}=A c, R_{2}=M e$

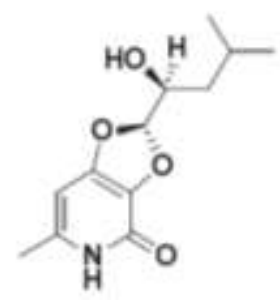

23

Figure 6. Secondary Metabolites of Aspergillus sp

New compounds pentacyclic lactam, diaporthalasin (26), ethyl trihydroxytridecatrienoate derivatives, diaporthacol (27), which was isolated as a triacetate derivative (28) (Khamthong, et al., 2014), R-mevalonolactone (29) (Amagata et al., 1998), dothiorelone C (30) (Sommart et al., 2009), (4S, 7S, 13S) -4.7dihydroxy-1,3-tetradeca-1,5-dienolide (31) (Mancilla et al. 2009), 4b-acetoxy-9b, 10b, 15a-trihydroxyprobotrydial (32) (Collado et al., 1995) and O-methyldihydrobotrydial (33) (Kimura et al., 1988) (Figure 7). The eighth these compounds were isolated from the marine-derived fungi Diaporthaceae sp. PSU-SP2 / 4 of the sponge from Pak Meng Beach, Sikao, Trang Province, Thailand (Khamthong et al., 2014). Diaporthalasin showed significant antibacterial activity against Staphylococcus aureus.

\section{Sponge as a Source of Marine Derived Fungi}

Marine-derived fungi have been isolated in a variety of substrates such as sediment, algae, mangrove and sponge. More than 40 metabolites of 15 strains of fungi have been isolated (Cheng et al., 1994, Yu et al., 1996, Doshida et al., 1996), are generally included in the genera of terrestrial habitats; eg Aspergillus (Abrell, Borgeson \& Crews 1996), Gymnascella (Numata et al., 1997, Amagata et al., 1998), and Trichoderma (Kobayashi et al., 1993). To date, more than 100 metabolites of marine-derived fungi isolated from marine sponges has been reported (Biabani \& Laatsch 1998). Some of the metabolites produced has a unique biological activity, such as cytotoxic,; eg gymnastatins A-E (Numata et al., 1997, Amagata et al., 1998). 


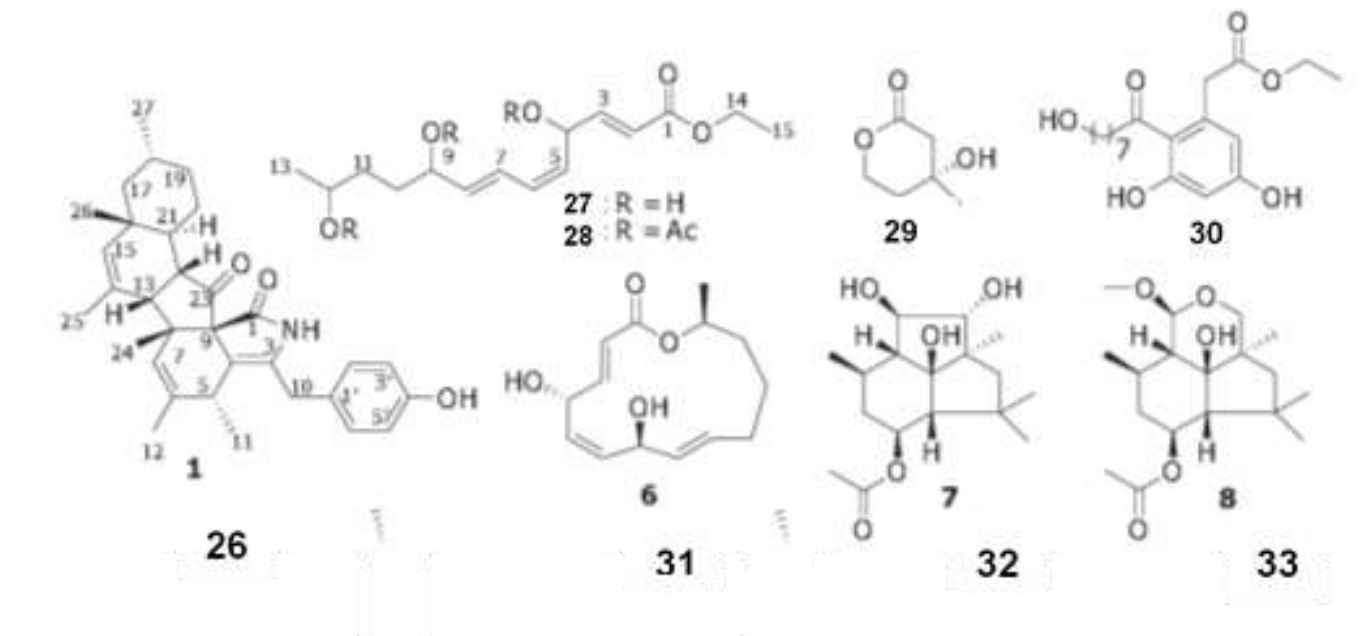

Figure 7. Secondary Metabolites of Diaporthaceae sp. PSU-SP2/4

Konig et al., (2000) reported the isolation of different media use only produce quantitative variation in the genus of fungi. 681 fungal strains were isolated from 16 species of sponge and into the 13 genera of Ascomycota, 2 of Zygomycota, and 37 fungi mitosporic; 37 strains remain sterile despite the use of a variety of media and culture conditions to induce sporulation. Fungus genus Acremonium, Aspergillus, Penicillium, Phoma, Fusarium is the most common genera isolated from the sponge. Krohn et al., 1992, 1994a, b also reported that the genus Acremonium, Aspergillus, Penicillium, Fusarium is a genus of the most frequently isolated from marine organisms.

Various methods have been carried out to isolate microorganisms from the marine environment, particularly sponge (Schulz et al., 1993). Isolation method performed on the surface of the sponge, so that the fungus isolated nature can not be determined whether mutualistic symbionts, parasites, or derived from the environment and is present by chance (Konig et al., 2000). Most marine-derived fungi isolates were isolated from the sponge of the terrestrial habitats genera (Roth, Orpurt \& Ahearn, 1964; Schaumann, 1974; Miller \& Whitney, 1981). Nevertheless unique secondary metabolites produced depends on the characteristics of each habitat (Kobayashi et al., 1993; Yu et al., 1996; Numata et al., 1997).
Konig et al., (2000) reported that $81.5 \%$ of the 92 fungal culture extracts were isolated from the sponge showed a relatively high proportion produce antimicrobial metabolites. Some fungal isolates from sponge also produces metabolites active against Mycobacterium tuberculosis and HIV-1 reverse transcriptase (RT) and tyrosine kinase (TK), an enzyme important target for the treatment of AIDS and cancer (Bolen and Brugge, 1997; Mitsuya and Broder, 1987 ). Fungi were isolated from the sponge is important as a source of new metabolites for pharmaceutical and agrochemical industries, all compounds isolated from the extracts, tested and biologically active. Moreover, the resulting compounds are generally new compounds with unique structures (Holler et al., 1999 a, b).

Based on the above description then, marine-derived fungi were isolated from the sponge is a competitive source for new natural products are biologically active. The high proportion of genera and new compounds showed that the fungus isolated from the sponge can be developed. As shown by Schulz et al., (1996, 1999a, b), the ecological niche plays an important role in the spread of the fungi. The new method of isolation should also be developed to selectively isolate marine-derived fungi from sponge, as it is likely that only a small portion of the fungi was isolated using conventional methods (Hawksworth, 1991). 
Marine derived fungi produces a higher proportion of new secondary metabolites such as those found fungi from the other extreme habitats (Dreyfuss, 1986 and Schulz et al., 1999b).

\section{CONCLUSION}

Marine-derived fungi are potential organisms to produce compounds with the unique structure and biological activity. Sponge is one organism that is the source of isolation of marine-derived fungi. The number of marine-derived fungi isolated from the sponge may differ in a number. In addition, the production of secondary metabolites produced by fungi depends on ecological niches. Secondary metabolites isolated from marine-derived fungi can be different even from the same host. This indicates that the isolation of compounds from marine-derived fungi is an opportunity to discover new compounds with unique and useful molecular structure.

\section{ACKNOWLEDGEMENTS}

Thank you to Prof. Ir. Yenny Risjani, DEA, Ph.D., and Director of Sekolah Tinggi Perikanan dan Kelautan (Institute of Fisheries and Marine) Palu for moral support so that the author could finish writing this article.

\section{REFERENCES}

Alhaddad, Z. A., Tanod, W. A., \& Wahyudi, D. (2019). Bioaktivitas Antibakteri Dari Ekstrak Daun Mangrove Avicennia sp. Jurnal Kelautan: Indonesian Journal of Marine Science and Technology, 12(1), 12-22.

Amador, M. L., Jimeno, J., Paz-Ares, L., Cortes-Funes, H., \& Hidalgo, M. (2003). Progress in the development and acquisition of anticancer agents frommarine sources. Ann Oncol, 14(11), 16071615.

Amagata, T., Tanaka, M., Yamada, T., Chen, Y.-P., Minoura, K., \& Numata, A. (2013). Additional cytotoxic substances isolated from the sponge-derived Gymnascella dankaliensis. Tetrahedron Letters, 54(45), 5960-5962. doi:10.1016/j.tetlet.2013.08.044

Amagata, T., Usami, Y., Minoura, K., Ito, T., Numata, A. (1998). Cytotoxic substances produced by a fungal strain from a sponge: physicochemical properties and structures. J. Antibiot, 51, 33-40.

Almeida, A. P., Dethoup, T., Singburaudom, N., Lima, R., Vasconcelos, M. H., Pinto, M., \& Kijjoa, A. (2010). The in vitro anticancer activity of the crude extract of the sponge-associated fungus Eurotium cristatum and its secondary metabolites. J. Nat. Pharm, 1, 25-29.

Barrow, C. J., \& Sedlock, D. M. (1994). 10(2-Phenyl-ethylene)ditryptophenaline, a new dimeric diketopiperazine from Aspergillus flavus. J. Nat. Prod., 57, 12391244.

Barrow, C. J., Cai, P., Snyder, J. K., Sedlock, D. M., Sun, H. H., \& Cooper, R. (1993). WIN 64821 a new competitive antagonist to substance $\mathrm{P}$, isolated from an Aspergillus species: structure determination and solution conformation. J. Org. Chem, 58, 6016-6021.

Blackwell, M. (2011). The Fungi: 1, 2, 3. 5.1 million species? American Journal of Botany, 98, 426-438.

Blunt, J. W., Copp, B. R., Munro, M. H. G., Northcote, P. T., \& Princep, M. R. (2006). Marine natural products. Nat Prod Rep, 23, 26-78.

Bolen, J. B. \& Brugge, J. S. (1997) Leucocyte protein kinases: potential targets for drug discovery. Annual Reviews of Immunology, 15, 371404.

Bringmann, G., Lang, G., Gulder, T. A. M., Tsuruta, H., Mühlbacher, J., Maksimenka, K., Müller, W. E. G. (2005). The first sorbicillinoid alkaloids, the antileukemic 
sorbicillactones $\mathrm{A}$ and $\mathrm{B}$, from a sponge-derived Penicillium chrysogenum strain. Tetrahedron, 61(30), 7252-7265. doi:10.1016/j.tet.2005.05.026.

Bringmann, G., Lang, G., Steffens, S., \& Schaumann, K. J. (2004). Petrosifungins $\mathrm{A}$ and $\mathrm{B}$, novel cyclodepsipeptides from a spongesderived strain of Penicillium brevicompactum. J. Nat. Prod., 67, $311-315$.

Bugni, T.S., \& Ireland, C.M. (2004). Marine-derived fungi: a chemically and biologically diverse group of microorganisms. Nat. Prod. Rep, 21, 143-163.

Bunzel, M., Ralph, J., Funk, C., \& Steinhart, H. (2003). Isolation and identification of a ferulic acid dehydrotrimer from saponified maize bran insoluble fiber. Eur. Food Res. Technol, 217, 128-133.

Butler, M. S., Capon, R. J., Nadeson, R., \& Beveridge, A. A. (1991). Aromatic Bisabolenes From An Australian Marine Sponge, Arenochalina sp. J. Nat. Prod, 54(2), 619-623.

Cai, S., Kong, X., Wang, W., Zhou, H., Zhu, T., Li, D., \& Gu, Q. (2012). Aspergilazine A, a diketopiperazine dimer with a rare $\mathrm{N}-1$ to $\mathrm{C}-6$ linkage, from a marine-derived fungus Aspergillus taichungensis. Tetrahedron Lett, 53, 2615-2617.

Collado, I.G., Herna'ndez-Galan, R., Dura' n-Patro' n, R., Cantoral, J.M. (1995). Metabolites from a shake culture of Botrytis cinerea. Phytochemistry, 38, 647-650.

Cueto, M., MacMillan, J. B., Jensen, P. R., \& Fenical, W. (2006). Tropolactones A-D, four meroterpenoids from a marinederived fungus of the genus Aspergillus. Phytochemistry, 67(16), 1826-31.

Cueto, M., Jensen, P.J., \& Fenical, W. (2002). Aspergilloxide, a novel sesterterpene epoxide from a marine-derived fungus of the genus
Aspergillus. Org. Lett, 4, 15831585.

Daferner, M., Anke, T., \& Sterner, O. (2002). Zopfiellamides A and B, antimicrobial tetramic acid derivatives from the marine fungus Zopfiella latipes. Tetrahedron, 58, 7781-7784.

D'Auria, M. V.; Minale, L.; \& Riccio, R. (1993). Polyoxygenated steroids of marine origin. Chem. Rev, 93, 1839-1895.

Debbab, A., Aly, A. H., \& Proksch, P. (2011). Bioactive secondary metabolites from endophytes and associated marine derived fungi. Fungal Divers., 49, 1-12.

Debbab, A., Aly, A. H., Lin, W. H., \& Proksch, P. (2010). Bioactive Compounds from Marine Bacteria and Fungi. Microb. Biotechnol., 3(5), 544- 563.

Dewanto, D. K., Finarti, F., Hermawan, R., Ndobe, S., Riyadi, P. H., \& Tanod, W. A. (2019). Aktivitas Antioksidan Ekstrak Karang Lunak Asal Teluk Palu, Sulawesi Tengah, Indonesia. Jurnal Pascapanen dan Bioteknologi Kelautan dan Perikanan, 14(2), 163-178.

Dewanto, D. K., \& Tanod, W. A. Finarti, \& Renol.(2018). Screening of Antiradical Activity from Some Central Sulawesi Mangroves. Pharmaciana, 8(1), 155-168.

Ding, G., Jiang, L., Guo, L., Chen, X., Zhang, H., \& Che, Y. (2008). Pestalazines and pestalamides, bioactive metabolites from the plant pathogenic fungus Pestalotiopsis theae. J. Nat. Prod., 71, 18611865.

Dreyfuss, M. M. (1986) Neue Erkenntnisse aus einem pharmakologischen Pilzscreening. Sydowia 39, 22-36.

Dunn, A.W., Johnstone, R.A.W., Sklarz, B., Lessinger, L., \& King, T.J. (1978). Andilesin, a C25 polyisoprenoid from Aspergillus sp.: X-ray crystallographic and spectroscopic determination of the structure. $J$. 
Chem. Soc., Chem. Commun., 533534.

Dunn, A.W., Johnstone, R.A.W., Sklarz, B., \& King, T.J. (1976). Isolation of C25 polyisoprenoids from Aspergillus sp.: crystal structure of andibe- nin. J. Chem. Soc., Chem. Commun., 270-271.

Faulkner, D. J. (2000). Marine pharmacology. Antonie Van Leeuwenhoek, 77(2), 135-145.

Faulkner, D. J. (1998) Marine natural products. Natural Products Reports, 15, 113-158.

Fenical, W., \& Jensen, P. R. (2006). Developing a new resource for drug discovery: marine actinomycete bacteria. Nat. Chem. Biol., 2, 666673.

Funk, C., Ralph, J., Steinhart, H., \& Bunzel, M. (2005). Isolation and structural characterisation of $8-O-4 / 8-O-4-$ and $\quad 8-8 / 8-O-4$-coupled dehydrotriferulic acids from maize bran. Phytochemistry, 66, 363-371.

Fusetani, N., Sugano, M., Matsunaga, S., \& Hashimoto, K. (1987). (+)Curcuphenol and dehydrocurcuphenol, novel sesquiterpenes which inhibit $\mathrm{H}, \mathrm{K}-$ ATPase, from a marine sponge Epipolasis sp. Experientia, 43(1112), 1234-1235.

Gallo, M. L., Seldes A. M., \& Cabrera G. M. (2004). Antibiotic long-chain and $\alpha, \beta$-unsaturated aldehydes from the culture of the marine fungus Cladosporium sp. Biochem. System. Ecol, 32, 545-551.

Gao, S.-S., Li, X.-M., Li, C.-S., Proksch, P., \& Wang, B.-G. (2011). Penicisteroids $\mathrm{A}$ and $\mathrm{B}$, antifungal and cytotoxic polyoxygenated steroids from the marine algaderived endophytic fungus Penicillium chrysogenum QEN24S. Bioorganic \& Medicinal Chemistry Letters, 21(10), 2894-7. doi:10.1016/j.bmcl.2011.03.076

Gao, Z., Li, B. L., Zheng, C. C., \& Wang, G. Y. (2008). Molecular detection of fungal communities in the Hawaiian Marine sponges Suberites zeteki and Mycale armata. Appl. Environ. Microbiol, 74, 6091-6101.

Garcia-Fernandez, L. F., Reyes, F., \& Sanchez-Puelles, J. M. (2002). Themarine pharmacy: new antitumoral compounds from the sea. Pharmaceut News, 9, 495-501.

Geiser, D. M. (2009). Sexual structures in Aspergillus: morphology, importance and genomics. Med. Mycol, 47 (Suppl. 1), S21-S26.

Gloer, J. B. (1997) Applications of fungal ecology in the search for new bioactive natural products. In The Mycota. Vol. 4. Environmental and Microbial Relationships (D. T. Wicklow \& B. E. So6 derstro6 m, eds): $\mathrm{xx}-\mathrm{xx} . \quad$ Springer Verlag, Berlin.

Gloer, J. B. (1995) The chemistry of fungal antagonism and defense. Canadian Journal of Botany, 73, S1265S1274.

Gomes, N. M., Dethoup, T., Singburaudom, N., Gales, L., Silva, A. M. S., \& Kijjoa, A. (2012). Eurocristatine, a new diketopiperazine dimer from the marine sponge-associated fungus Eurotium cristatum. Phytochemistry Letters, 5(4), 717720. doi:10.1016/j.phytol.2012.07.010

Haefner, B. (2003).Drug from the deep: marine natural products as drug candidates. Drug Discov Today, 8(12), 536-544.

Hamasaki, T., Nagayama, K., \& Hatsuda, Y. (1978). Two new metabolites, sydonic acid and hydroxysydonic acid, from Aspergillus sydowi. Agric. Biol. Chem, 42, 37-40.

Hawksworth, D. L. (1991) The fungal dimension of biodiversity: magnitude, significance, and conservation. Mycological Research, 95, 641-655.

Henne, P., Thiericke, R., Grabley, S., Hütter, K., Wink, J., Jurkiewicz, E., \& Zeeck, A. (1993). Secondary 
Metabolites by Chemical Screening, 23. Waraterpols, New Penicillium Metabolites and Their Derivatives. Liebigs Ann. Chem, 1993(5), 565-571.

HÖller, U., KÖnig, G. M. \& Wright, A. D. (1999a) Three new metabolites from marine-derived fungi of the genera Coniothyrium and Microsphaeropsis. Journal of Natural Products, 62, 114-118.

HÖller, U., KÖnig, G. M. \& Wright, A. D. (1999b) A new tyrosine kinase inhibitor from a marine isolate of Ulocladium botrytis and new metabolites from the marine fungi Asteromyces cruciatus and Varicosporina ramulosa. European Journal of Organic Chemistry, 1999, 2949-2955.

Igarashi, Y., Sekine, A., Fukazawa, H., Uehara, Y., Yamaguchi, K., Endo, Y., Okuda, T., Furumai, T., \& Oki, T. (2002). Anicequol, a novel inhibitor for anchorage-independent growth of tumor cells from Penicillium aurantiogriseum Dierckx TPF0213. J. Antibiot., 55, 371-376.

Ivanchina, N. V., Kicha, A. A., Kalinovsky, A. I., Dmitrenok, P. S., Prokof'eva, N. G., \& Stonik, V. A. (2001). New Steroid Glycosides from the Starfish Asterias rathbuni. J. Nat. Prod., 64, 945-947.

John, L. M. D., Tinto, W. F., McLean, S., \& Reynolds, W. (1993). Acerosterol, A Novel Polyhydroxylated Sterol From The Gorgonian Octocoral Pseudopterogorgia-acerosa. J. Nat. Prod, 56, 144-146.

Khamthong, N., Rukachaisirikul, V., Phongpaichit, S., Preedanon, S., \& Sakayaroj, J. (2014). An antibacterial cytochalasin derivative from the marine-derived fungus Diaporthaceae sp. PSU-SP2/4. Phytochemistry Letters, 10, 5-9. doi:10.1016/j.phytol.2014.06.01.

Kimura, Y., Fujioka, H., Nakajima, H., Hamasaki, T., Isogai, A. (1988).
Isolation and structures of $\mathrm{O}$ methyldihydrobotrydial and deacetyl-O-methyldihydrobotrydialone produced by Botryis squamosa. Agric. Biol. Chem., 52, 1845-1847.

Kobayashi, M., Uehara, H., Matsunami, K., Aoki, S. \& Kitagawa, I. (1993) Trichoharzin, a new polyketide produced by the imperfect fungus Trichoderma harzianum separated from the marine sponge Micale cecilia. Tetrahedron Letters, 34, 7925-7928.

Koenig, G.M., Kehraus, S., Seibert, S.F., Abdel-Lateff, A., Mu"eller, D. (2006). Natural products from marine organisms and their associated microbes. Chem. Bio. Chem., 7, 229-238.

Koenig, G. M., Draeger, S., Wright, A. D., $\&$ Matthe, G. F. (2000). Fungi from marine sponges: diversity , biological activity and secondary metabolites, 104(November), 1354-1365.

Krohn, K., Michel, A., Florke, U., Aust, H.J., Draeger, S. \& Schulz, B. (1994a) Palmarumycins $\mathrm{CP}$ "-CP\% from Coniothyrium palmarum: isolation, structure elucidation and biological activity. Liebigs Annalen der Chemie, 1994, 1093-1097.

Krohn, K., Michel, A., Florke, U., Aust, H.J., Draeger, S. \& Schulz, B. (1994b) Palmarumycins C"-C"' from Coniothyrium sp. : Isolation, structure elucidation and biological activity. Liebigs Annalen der Chemie, 1994, 1099-1108.

Krohn, K., Franke, C., Jones, P., Aust, H.J., Draeger, S. \& Schulz, G. (1992) Isolierung, Synthese und biologische Wirkung von Coniothyriomycin sowie Synthese und Biotestung analoger offenkettiger Imide. Liebigs Annalen der Chemie, 1992, 789798.

Kudo, S., Murakami, T., Miyanishi, J., Tanaka, K., Takada, N., \& 
Hashimoto, M. (2009). Isolation and absolute stereochemistry of optically active sydonic acid from Glonium sp. (Hysteriales, Ascomycota). Biosci. Biotechnol. Biochem, 73(1), 203-204.

Lee, J.-C., Hou, M.-F., Huang, H.-W., Chang, F.-R., Yeh, C.-C., Tang, J.Y., Chang, H.-W. (2013). Marine algal natural products with antioxidative, anti-inflammatory, and anti-cancer properties. Cancer Cell Int , 13, 55-63.

Li, G. Y., Yang, T., Luo, Y. G., Chen, X. Z., Fang, D. M., \& Zhang, G. L. (2009). Brevianamide J, a new indole alkaloid dimer from fungus Aspergillus versicolor. Org. Lett., 11, 3714-3717.

Lin, Z., Zhang, G., Zhu, T., Liu, R., Wei, H., \& Gu, Q. (2009). Bioactive cytochalasins from Aspergillus flavipes, an endophytic fungus associated with the mangrove plant Acanthus ilicifolius. Helv. Chim. Acta, 92, 1538-1544.

Liu, H., Edrada-Ebel, R. A., Ebel, R., Wang, Y., Schulz, B., Draeger, S., Müller, W. E. G., Wray, V., Lin, W. H., \& Proksch, P. (2011). Ophiobolin sesterterpenoids and pyrrolidine alkaloids from the sponge-derived fungus Aspergillus ustus. Helv. Chim. Acta, 94, 623631.

Liu, H., Edrada-Ebel, R. A., Ebel, R., Wang, Y., Schulz, B., Draeger, S., Müller, W. E. G., Wray, V., Lin, W., \& Proksch, P. (2009). Drimane sesquiterpenoids from the fungus Aspergillus ustus isolated from the marine sponge Suberites domuncula. J. Nat. Prod., 72, 1585-1588.

Loesgen, S., Bruhn, T., Meindl, K., Dix, I., Schulz, B., Zeek, A., \& Bringmann, G. (2011). (+)-Flavipucine, the Missing Member of the Pyridione Epoxide Family of Fungal Antibiotics. Eur. J. Org. Chem., 26, 5156-5162.
Lopez-Gresa, M. P., Cabedo, N., GonzalezMas, M. C., Ciavatta, M. L., Avila, C., \& Primo, J. (2009). Terretonins $\mathrm{E}$ and $\mathrm{F}$, inhibitors of the mitochondrial respiratory chain from the marine-derived fungus Aspergillus insuetus. J. Nat. Prod., 72, 1348-1351.

Lordan, S., Ross, R. P., \& Stanton, C. (2011). Marine bioactives as functional food ingredients: potential to reduce the incidence of chronic diseases. Mar Drugs, 9, 1056-1100.

Lu, Z. Y., Zhu, H. J., Fu, P., Wang, Y., Zhang, Z. H., Lin, H. P., Liu, P. P., Zhuang, Y. B., Hong, K., \& Zhu, W. M. (2010). Cytotoxic polyphenols from the marinederived fungus Penicillium expansum. J. Nat. Prod, 73(5), 911914.

Mancilla, G., Jime' nez-Teja, D., Femenı'aRi'os, M., Maci'as-Sa' nchez, A.J., Collado, I.G., Herna'ndez-Gala' n, R. (2009). Novel macrolide from wild strains of the phyto-pathogen fungus Colletotrichum acutatum. Nat. Prod. Commun., 4, 395-398.

Mansoor, T. A., Lee, Y. M., Hong, J., Lee, C. O., Im, K. S., \& Jung, J. H. (2006). 5,6:8,9-Diepoxy and Other Cytotoxic Sterols from the Marine Sponge Homaxinella sp. J. Nat. Prod, 69, 131-134.

Mansoor, T. A., Hong, J., Lee, C. O., Bae, S. J., Im, K. S., \& Jung, J. H. (2005). Cytotoxic sterol derivatives from a marine sponge Homaxinella sp. J. Nat. Prod, 68(3), 331-336.

Mayer, A. M \& Gustafson, K. R. (2003). Marine pharmacology in 2000: antitumor and cytotoxic compounds. Int J Cancer,105(3), 291-299.

Mayer, A. M., \& Lehmann, V. K. (2001). Marine pharmacology in 1999: antitumor and cytotoxic compounds. Anti- cancer Res, 21(4A), 2489-2500. 
McEnroe, F. J., \& Fenical, W. (1978). Structures and synthesis of some new antibacterial sesquiterpenoids from the gorgonian coral Pseudopterogorgia rigida. Tetrahedron, 34, 16611664.

Miller, J. D. \& Whitney, N. J. (1981) Fungi of the Bay of Fundy III. Geofungi in the marine environment. Marine Biology, 65, 61-68.

Mitsuya, H. \& Broder, S. (1987) Strategies for antiviral therapy in AIDS. Nature, 325, 773-778.

Mülhaupt, T., Kaspar, H., Otto, S., Reichert, M., Bringmann, G., \& Lindel, T. (2005). Isolation, Structural Elucidation, and Synthesis of Curcutetraol. Eur. J. Org. Chem, 2005(2), 334-341.

Nukina, M., Sato, Y., Ikeda, M., Sassa, T. (1981). A new fungal morphogenic substance produced by an unidentified Aspergillus sp. Agric. Biol. Chem, 45, 789-790.

Numata, A., Amagata, T., Minoura, K. \& Ito, T. (1997) Gymnastatins, novel cytotoxic metabolites produced by a fungal strain from a sponge. Tetrahedron Letters, 38, 56755678.

Ovenden, S. P. B., Sberna, G., Tait, R. M., Wildman, H. G., Patel, R., Li, B., Steffy, K., Nguyen, N., \& MuererGrimes, B. M. (2004). A diketopiperazine dimer from amarine-derived isolate Aspergillus niger. J. Nat. Prod., 67, 20932095.

Proksch, P., Edrada, R. A., \& Ebel, R. (2002). Drugs from the seascurrent status and microbiological implications. Appl Microbiol Biotechnol, 59(2-3), 125- 134.

Rateb, M. E., \& Ebel, R. (2011). Secondary metabolites of fungi from marine habitats. Nat. Prod. Rep, 28(2), 290-344.

Raghukumar, S. (1990). Speculations on niches occupied by fungi in the sea with relation to bacteria.
Proceedings of Indian Academy of Science, Plant Science, 100, 129138.

Roth, F. J., Orpurt, P. A. \& Ahearn, D. G. (1964) Occurrence and distribution of fungi in a subtropical marine environment. Canadian Journal of Botany, 42, 375-383.

Rowley, D.C., Kelly, S., Kauffman, C.A., Jensen, P.R., \& Fenical, W. (2003). Halovirs A-E, new antiviral agents from a marine-derived fungus of the genus Scytalidium. Biorg. Med. Chem, 11, 4263-4274.

Ruju, R., Piggott, A. M., Conte, M., Aalbersberg, W. G. L., Feussner, K., \& Capon, R. J. (2009). Naseseazines A and B: a new dimeric diketopiperazine framework from amarine-derived Actinomycete, Streptomyces sp. J. Org. Lett., 11, 3862-3865

Saleem, M., Ali, M. S., Hussain, S., Jabbar, A., Ashraf, M., \& Lee, Y. S. (2007). Marine natural products of fungal origin. Nat. Prod. Rep., 24, 1142-1152.

Sang, U. L., Yukihiro, A., Dongho, L., JaeHyuk, J., Jong, S. A., \& Hyuncheol, O. (2011). Protuboxepins A and B and Protubonines A and B from the Marine-Derived Fungus Aspergillus sp. SF-5044. J. Nat. Prod., 74(5), 1284-1287.

Schaumann, K. (1974) Zur Verbreitung saprophytischer ho6 herer Pilzkeime in der Hochsee und dem NO-Atlantik. Vero? ffentlichungen des Instituts fu? r Meeresforschung Bremerhaven, Supplement, 5, 287300.

Schulz, B., Draeger, S., Aust, H.-J., Krohn, K., Franke, C., Ludewig, K., Bahramsari, R., Roemer, E., Kliche-Spory, C., Beckmann, K., Biele, C., Drogies \& John, M. (1999a) Fungitoxische Metaboliten aus endophytischen und bodenbu6 rtigen Pilzen. Aktuelle Enwicklungen in der 
Naturstofforschung: 11 . Irseer Naturstofftage der DECHEMA e.V.

Schulz, B., RÖmmert, A.-K., Dammann, U., Aust, H.-J. \& Strack, D. (1999b) The endophyte host interaction: a balanced antagonism. Mycological Research, 103, 12751283.

Schulz, B., Peters, S., Draeger, S., Aust, H.J., Krohn, K., Ludewig, K., Bahramsari, R., Roemer, E., Klische-Spory, C., Michel, A., Beckmann, K. \& Drogies, K. H. (1996) Herbizid wirksame Metaboliten aus Endophyten. Dechema Symposium: 8. Irseer Naturstofftage der Dechema e.V.

Schulz, B., Wanke, U., Draeger, S. \& Aust, H-J. (1993) Endophytes from herbaceous plants and shrubs: effectiveness of surface sterilisation methods. Mycological Research, 97, 1447-1450.

Smetania, O. F., Kalinovsky, A. I., Khudyakova, Y. V., Pivkin, M. V., Dmitrenok, P.S., \& Fedorov, S. N. (2007). Indole alkaloids produced by a marine fungus isolate of Penicillium janthinellum Biourge. $J$ Nat Prod, 70, 906-909.

Sommart, U., Rukachaisirikul, V., Sukpondma, Y., Phongpaichit, S., Towatana, N.H., Graidist, P., Hajiwangoh, Z., Sakayaroj, J. (2009). A cyclohexenone derivative from Diaporthaceous fungus PSUH2. Arch. Pharm. Res., 32, 12271231.

Son, B. W., Jensen, P. R., Kauffman, C. A., \& Fenical, W. (1999). New cytotoxic epidithiodioxopiperazines related to verticillin A from a marine isolate of the fungus Penicillium. Nat. Prod. Lett., 13, 213-222.

Sun, L.-L., Shao, C.-L., Chen, J.-F., Guo, Z.-Y., Fu, X.-M., Chen, M., ... Wang, C.-Y. (2012). New bisabolane sesquiterpenoids from a marine-derived fungus Aspergillus sp. isolated from the sponge
Xestospongia testudinaria.

Bioorganic \& Medicinal Chemistry

Letters, 22(3), 1326-9.

doi:10.1016/j.bmcl.2011.12.083

Takahashi, C., Takai, Y., Kimura, Y., Numata, A., Shigematsu, N., \& Tanaka, H. (1995a). Cytotoxic metabolites from a fungal adherent of a marine alga. Phytochemistry, 38, 155-158.

Takahashi, C., Minoura, K., Yamada, T., Numata, A., Kushida, K., Shingu, T., Hagishita, S., Nakai, H., Sato, T., \& Harada, H. (1995b). Potent cytotoxic metabolites from a Leptosphaeria species. Structure determination and conformational analysis. Tetrahedron, 51, 34833498.

Takahashi, C., Numata, A., Ito, Y., Matsumura, E., Araki, H., Iwaki, H., \& Kushida, K. (1994). Leptosins, antitumour metabolites of a fungus isolated from a marine alga. J. Chem. Soc. Perkin Trans., 1, 1859-1864.

Tan, R.X., Jensen, P.R., Williams, P.G., \& Fenical, W. (2004). Isolation and structural assignments of rostratins A-D, cytotoxic disulfides produced by the marine-derived fungus Exserohilium rostratum. J. Nat. Prod, 67, 1374-1382.

Tanod, W. A., Aristawati, A. T., \& Muliadin, M. (2018). Soft Coral (Sinularia sp.) Extracts with Antibacterial Activity. OmniAkuatika, 14(1). 108-117.

Tasdemir, D., Bugni, T. S., Mangalindan, G. C., Concepción, G. P., Harper, M. K., \& Ireland, C. M. Turk. (2003). Bisabolane type sesquiterpenes from a marine Didiscus sponge. J. Chem, 27, 273279.

Varoglu, M., Corbett, T. H., Valeriote, F. A., \& Crews, P. (1997). Asperazine, a selective cytotoxic alkaloid from a sponge-derived culture of Aspergillus niger. J. Org. Chem, 62, 7078-7079. 
Vasanthabharathi, V., \& Jayalakshmi, S. (2013). Bioactive Potential Of Marine Microbes. African Journal of Microbiology Research, 7(39), 4683-4688.

Velmurugan, S., Prasannakumar, C., Manokaran, S., Ajith Kumar, T., Samkamaleson, A., \& Palavesam, A. (2013). DNA barcodes for marine fungal identification and discovery. Fungal Ecology, 6(5), 408-418.

doi:10.1016/j.funeco.2013.05.003

Wei, M. Y., Wang, C. Y., Liu, Q. A., Shao, C. L., She, Z. G., \& Lin, Y. C. (2010). Five sesquiterpenoids from a marine-derived fungus Aspergillus sp. isolated from a gorgonian Dichotella gemmacea. Mar. Drugs, 8(4), 941-949.

Wijesekara, I., Zhang, C., Van Ta, Q., Vo, T.-S., Li, Y.-X., \& Kim, S.-K. (2014). Physcion from marinederived fungus Microsporum sp. induces apoptosis in human cervical carcinoma HeLa cells. Microbiological Research, 169(4), 255-61.

doi:10.1016/j.micres.2013.09.001

Wright, A. E., Pomponi, S. A., McConnell, O. J., Kohmoto, S., \& McCarthy, P. J. (1987). (+)-Curcuphenol and (+)Curcudiol, Sesquiterpene Phenols from Shallow and Deep Water Collections of the Marine Sponge Didiscus flavus. J. Nat. Prod, 50(5), 976-978.
Yamada, T., Iwamoto, C., Yamagaki, N., Yamanouchi, T., Minoura, K., Yamori, T., Uehara, Y., Andoh, T., Umemura, K., \& Numata, A. (2002). Leptosins M-N1, cytotoxic metabolites from a Leptosphaeria species separated from a marine alga. Structure determination and biological activities. Tetrahedron, 58, 479-487.

Yu, C.-M., Curtis, J. M., Walter, J. A., Wright, J. L. C., Ayer, S. W., Kaleta, J., Querengesser, L. \& Fathi-Afshar, Z. R. (1996) Potent inhibitors of cysteine proteases from the marine fungus Microascus longirostris. Journal of Antibiotics, 49, 395-397.

Zhang, H., Zhang, J., Hu, S., Zhang, Z., Zhu, C., Ng, S. W., \& Tan, R. (2010).

Ardeemins and cytochalasins from Aspergillus terreus residing in Artemisia аппиа. Planta Med., 76, 1616-1621.

Zhou, Y., Debbab, A., Wray, V., Lin, W., Schulz, B., Trepos, R., ... Aly, A. H. (2014). Marine bacterial inhibitors from the sponge-derived fungus Aspergillus sp. Tetrahedron Letters, 55(17), 2789-2792. doi:10.1016/j.tetlet.2014.02.062

Zhou, Y., Mándi, A., Debbab, A., Wray, V., Schulz, B., Müller, W. E. G., Lin, W., Proksch, P., Kurtán, T., \& Aly, A. H. Eur. (2011). New Austalides from the Sponge-Associated Fungus Aspergillus sp. J. Org. Chem., 2011(30), 6009-6019. 